\title{
Keseimbangan Badan dan Jiwa Perspektif Abu Zaid Al-Balkhi
}

\author{
Musfichin \\ Universitas Islam Negeri (UIN) Antasari Banjarmasin
}

\begin{abstract}
Abu Zaid al-Balkhi was a multi-talent scientist in 9th-century Islam in several fields, his ability to write two themes in a systematic work had brought him to be known as the first mental health pioneer who before that time prioritized physical health. The purpose of this study is to describe the concept of Body and Soul according to Abu Zaid al-Balkhi, using the Research Library method from the data of Abu Zaid al-Balkhi's work entitled "Mashalih al-Abdan wal-Anfus" and from other sources related to research. This study found 2 (two) topics, among others: 1. The importance of maintaining body and soul health, namely body health as in general principles of health science such as maintaining environmental health, shelter, water, and air sanitation, while for mental health the importance of preserving mind and feelings, 2. Differentiation of treatment/treatment in dealing with neurosis and psychosis disorders, for neurotic disorders the therapeutic process is carried out with cognitive therapy while for psychosis disorders the therapeutic process is done spiritually, thus the importance of maintaining a balance of body and soul for health, otherwise imbalance will cause disease.
\end{abstract}

Keywords: Balance; Body; Soul; Abu Zaid Al-Balkhi

\begin{abstract}
Abstrak
Abu Zaid al-Balkhi merupakan ilmuwan Islam abad ke-9 M yang multitalent dibeberapa bidang, kemampuanya menulis dua tema dalam satu karya yang sistematis telah membawa dirinya dikenal sebagai perintis kesehatan mental pertama yang sebelumnya pada masa itu lebih mementingkan kesehatan fisik. Tujuan penelitian ini untuk mengetahui gambaran konsep Badan dan Jiwa menurut Abu Zaid al-Balkhi, menggunakan metode library Research dari data karya Abu Zaid al-Balkhi yang berjudul "Mashalih al-Abdan wal-Anfus" dan dari sumber lain yang berkaitan dengan penelitian. Penelitian ini menemukan 2 (dua) bahasan antara lain: 1. Pentingnya menjaga kesehatan badan dan jiwa yaitu kesehatan badan sebagaimana pada prinsip-prinsip umum ilmu kesehatan seperti menjaga kesehatan lingkungan, tempat tinggal, sanitasi air dan udara, sedangkan untuk kesehatan jiwa pentingnya menjaga pikiran dan perasaan, 2. Pembedaan perawatan/terapi dalam menangani gangguan neurosis dan psikosis, untuk gangguan neurosis proses terapi dilakukan dengan terapi kognitif sedangkan untuk gangguan psikosis proses terapi dilakukan dengan spiritual, Demikian pentingnya menjaga keseimbangan badan dan jiwa untuk kesehatan, sebaliknya ketidakseimbangan akan menyebabkan penyakit.
\end{abstract}

Kata Kunci: Keseimbangan; Badan; Jiwa; Abu Zaid Al-Balkhi 
Manusia merupakan makhluk yang paling sempurna (QS. At Tiin, 95:4) berbeda dengan makhluk lainnya (QS. Al Isra', 17: 70; QS. Al-Syam, 91: 8), bahwa diciptakannya manusia hanya untuk beribadah (QS. Adz-Dzariyaat, 51: 56), dalam keseharian kerangka aktifitas umat Islam selalu mendasarkan pada Al-Qur'an, dan hadis serta penjelas operasional dalam ijtihad para ilmuwan Islam lain. Beberapa aktifitas tersebut telah mengasilkan karya-karya besar yang sampai kini masih terus dibaca dan dikaji, seperti: Al Ash'ath Bin Qais Al-Kindi (801-866), Ali lbn Sahl Rabban At-Tabari (838-870), Abu Zaid Al-Balkhi (850-934), Abu Bakr Mohammad lbn Zakariya Al-Razi (864-932), Abu Nasr Mohammad Ibn Al-Farakh (Al-Farabi) (870-950), Abul Hasan Ali Abbas Al-majusi (D. 995), Ikhwan Al-Safa: The Bretheren of Purity (10th century A.D.), Abu Ali Ahmad B. Muhammad B. Ya'kub Ibn Miskawayh (941-1030), Abu 'Ali Al-Husayn B. 'Abd Allah lbn Sina (9801037), Abu Hamid Muhammad Al-Ghazali (1058-1111), Abu Bakr Mohammed Bin Yahya Al-Saigh lbn Bajjah (1095-1138), lbn Al-Ayn Zarbi (D. 1153), Abu Bakar Muhammad Bin Abdul Malik lbn Tufayl (1110-1185), Abu'l Walid Muhamad Bin Ahmad lbn Rushd (1126-1198), Fakhr Al-Din Muhammad Umar Al Razi (1149/50-1209), Muhyid-Din Muhammad Ibn Ali (Ibn Arabi) (1164-1240) dan lain-lain (Haque, 2004).

Kontribusi besar yang dilakukan mereka dapat dikatakan unik karena mendasarkan pada Tauhid (Unity of God), untuk mengenal Tuhan seorang ilmuwan muslim menjelaskannya dengan istilah yang berlaku pada ciptaan-Nya, meskipun konsep-konsep tersebut bersifat sangat abstrak, namun ilmuwan muslim mampu membingkai pengetahuan dalam bahasa Islam sebagai cermin atas konsep ketuhanan dimana ilmu pengetahuan dapat dikembangkan dan disempurnakan (al -Faruqi, 1992), berbeda kajian modern yang lebih mengutamakan murni sains/antroposentris dalam mempelajari manusia mengenyampingkan aspek spiritual (Badri, 2013a).

Abad keemasan Islam (750 M-1258 M) merupakan masa dimana dunia Islam menghasilkan para ilmuwan Islam yang memiliki kontribusi besar terhadap perkembangan teknologi dan kebudayaan dunia, disamping semangat menjaga tradisi untuk melakukan suatu inovasi mereka sendiri. Terkait dengan bidang psikologi yang dimulai pada abad 19, para ilmuwan Islam telah banyak menulis mengenai perilaku manusia, meskipun istilah 'psikologi' belum dikenal pada waktu itu, mengingat kegiatan-kegiatan tersebut masih menjadi bagian 
tulisan-tulisan filosofis, seperti penggunakan istilah-istilah jasad (al-jism), jiwa (an-nafs), roh (arruh), hati (al-qolb), akal (al-aql), dan lain sebagainya (Al-Ghazālī, 1982); (Abdul Mujib \& Mudzakir, 2002). Filsafat dalam istilah sederhana mengacu pada pengetahuan tentang semua hal (the knowledge of all things).(Nasr \& Leaman, 2013) Perkembangan berikutnya bahasan mengenai psikologi mereka menggunakan istilah Nafs (diri atau jiwa) untuk menunjukkan kepribadian individu dan model sifat manusia. Secara umum Ilmuwan Islam menyebutnya dengan Ilm-al Nafsiat atau pengetahuan diri, nafs adalah istilah luas yang mencakup qalb (hati), ruh (roh), aql (intelek) dan irada (kehendak) (Ashy, 1999). Ini merupakan satu gagasan orisinal dan kontribusi dari ilmuan Islam dibidang psikologi disamping teori dan praktik psikologi modern, juga menjadi suatu pilihan mengurai tantangan yang dihadapi umat Islam saat ini serta menjadi arah adaptasi dengan teori-teori Barat. Rekomendasi tentang indigenisasi psikologi bagi masyarakat Muslim tentu sangat menarik dalam mencari formula perspektif Islam mengenai perilaku manusia (Haque, 2004).

Gagasan-gagasan penting perspektif Islam mengenai perilaku manusia dalam karyakarya ilmuwan Islam salah satunya dapat ditemukan dalam karya Abu Zayd al-Balkhi berjudul "Al-Masalih al-Abdan wal-Anfus" buku ini ditemukan pertama kali pada Tahun 1984 oleh Fuat Sezgin yaitu seorang professor emeritus dari Johann Wolfgang Goethe University di Frankfurt dan diterbitkan oleh the Institute of the History of the Arab Islamic Sciences (Germany) (Badri, 2013a). Pada tahun 2005 oleh World Health Organization manuscriptnya di tahqiq oleh Mahmud Misri, (Al-Balhi, 2005) dan tahun 2013 karya ini diterjemahkan ke dalam Bahasa Inggris oleh Malik Badri dengan judul Sustenance of the Soul: The Cognitive Behaviour Therapy of a Ninth Century Physician.(Badri, 2013a) Oleh karena itu penulis merasa tertarik memahami karya Abu Zayd alBalkhi ini untuk dapat memperoleh pemahaman atas konsep badan dan jiwa Abu Zayd al-Balkhi terkait dengan bidang psikologi Islam.

\section{Metode}

Penelitian ini merupakan penelitian literatur untuk memperoleh data secara kualitatif. Penelitian ini difokuskan pada konsep keseimbangan badan dan jiwa perspektif Abu Zaid AlBalkhi. Objek penelitian ini sebagaimana dikemukakan tadi digali dari berbagai literatur. 
Penelusuran data litartur dilakukan terhadap dokumen, buku, jurnal maupun tokoh masyarakat terutama informasi tentang keseimbangan badan dan jiwa perspektif Abu Zaid AlBalkhi.

\section{Hasil dan Pembahasan}

\section{Profil Abu Zaid al-Balkhi}

Abu Zayd al-Balkhi (235-322 H / 849 -934 M) memiliki nama asli Ahmad ibn Sahl merupakan seorang ilmuwan Islam yang memiliki kemampuan diberbagai bidang, meliputi bidang geografi, kedokteran, teologi, politik, filsafat, puisi, sastra, tata bahasa Arab, astrologi, astronomi, matematika, biografi, etika, sosiologi serta lainnya, sebagaimana indeks (الفهرست) Muhammad ibn Ishaaq al-Nadim disebutkan al-Balkhi memiliki lebih dari 55 karya dari beberapa disiplin ilmu pengetahuan, demikian dikutip dari Yaqut al-Hamawi dalam kitabnya "Mu'jam al-Udaba" (Al-Hamawi, 1993). Sedangkan dalam buku Mahmud Misri menyebutkan al-Balkhi memiliki kurang lebih 64 buku, sebagaimana dikutip oleh Abu Hayyan (ابو حيان) dan al-Fahru al-Razi (فخر الرازي), namun dari karya-karya itu hanya dua kitab yang sampai pada kita yaitu kitab suwar al-aqalim (صور الاقاليم) di bidang geografi dan masalih al abdan wal anfus (مصالح di bidang psikologi (Al-Balhi, 2005).

Al-Balkhi lahir di Syamistiyan sekarang bagian wilayah Afghanistan. Ayahnya adalah seorang guru taman kanak-kanak. Pada masa remaja Al-Balkhi pergi ke Baghdad selama 8 (delapan) tahun untuk menimba ilmu syariat (العلوم الثرعيه) dan berjumpa dengan Abu Yusuf Ya'qub ibn Ishaq al-Kindi kemudian berguru kepadanya, dari sinilah awal Al-Balkhi memulai dasar pengembangan kajian keilmuan berikutnya (Al-Balhi, 2005).

\section{Kitab Mashalih al-Abdan wal-Anfus}

Kitab ini membahas tema-tema yang berkenaan dengan menjaga kesehatan badan (

dan menjaga kesehatan badan jiwa (حفظ صحة البدن) Kitab masalih al abdan wal anfus ( صحة البدن (الابدان والانفس yang manuskripnya tersimpan di Perpustakaan Ayasofya (the Ayasofya Library) Istambul Turki,(Badri, 2013a, hlm. 10) terdiri dari dua bagian, yakni Mashalih al-abdan yang 
mencakup 14 (empatbelas) bab dan masalih al-anfus yang mencakup 8 (delapan) bab (Al-Balhi, 2005).

Bagian pertama yang mencakup 14 (empatbelas) bab tersebut antara lain: Bab pertama: menerangkan tentang batas/ukuran keperluan tubuh yang harus dipenuhi, dan manfaat yang perolehnya ( الباب الاول: فى الاخبار عن مبلغ الحاجة الى تعهد الابدان, ومنفعة ذللك وعائدته Bab kedua: Deskripsi tentang permulaan segala sesuatu, awal mula sifat/karakter dan penciptaan manusia, serta perkembangan anggota tubuhnya (الباب الثانى: في وصف او ائل الاشياء, وبدء طبيعة الانسان وخلقته وتركيب اعضائه). Bab ketiga: Menerangkan tentang pengaturan tempat tinggal, Air dan udara ( الباب الثالث: فى تدبير

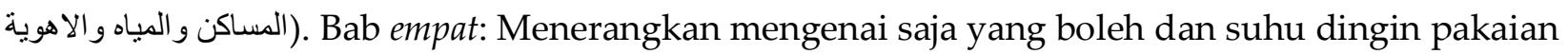
الباب الخامس: فى (الباب الر ابع: فى تدبير ما بقي الحر و البرد من الاكنان و الملابس ). Bab lima: pengelolaan makanan (تدبير المطاعم), Bab enam: pengelolaan minuman (الباب السادس: فى تدبير المشارب), Bab ketujuh: mengatur pencahayaan matahari (الباب السابع: فى تدبير المشمومات), Bab kedelapan: mengatur jam tidur ( الباب الثامن: (فى تدبير النوم), Bab kesembilan: mengatur bak mandi (الباب التاسع: فى تدبير الباه), Bab kesepuluh: mengatur ventilasi udara (الباب العانثر: فى تدبير الاستحتام), Bab kesebelas: mengatur olah raga ( الباب الحادي عشر: في تدبير الباب الثانى عشر: في تدبير (الحركات الرياضية Bab kedua belas: mengelola olah raga terhadap gerak badan الباب الثالث عشر: في تدبير (الحركات الرياضيه من غمز البدن ودلكه السماع). Bab keempat belas: mengatur pemulihan kesehatan (الباب الرابع عشر: في تدبير اعادة الصحم).

Sedangkan pada bagian kedua meliputi: Bab pertama: Mambahas jumlah kebutuhan الباب الاول: في الاخبار عن مبلغ الحاجة الى تدبير مصالح (kesehatan) jiwa الانفس الثانى: في تدبير حفظ صحة الانفس ( Bab kedua: memanajemen pemeliharaan kesehatan jiwa (الباب ) (عليها ), Bab ketiga: Manajemen pemulihan kesehatan jiwa saat sakit (الباب الثالث: في تدبير اعادة صحة الانفسا الباب الر ابع: في ) Bab kempat: Mengklasifikasi dan membatasi berbagai gejala psikologis (اذا فقدت اليها الباب الخامس: في تدبير صرف ( ذكر الاعر اض النفسانية وتعديدها (الغضب وقمعه (الباب السادس: في تدبير تسكين الخوف و الفزع ), Bab keenam: Menghilangkan phobia dan panik ), Bab ketujuh: Menghilangkan rasa depresi dan keluh kesah (الباب السابع: فى تدبير دفع الحزن و الجزع), Bab kedelapan: Mengatasi kegundahan hati dan mengatur bisikan hati ( الباب الثامن: فى الاحتيال لدفع وسواس (الصدر واحاديث النفس (Al-Balhi, 2005).

Pembahasan al-Balkhi dapat dikatakan sangat komplit karena dua tema berbeda dibahas dalam satu karya yang sistematis, selain itu dia merupakan perintis pertama kesehatan 
mental yang sebelumnya belum diketahui bahwa ilmu psikiatri dan kesehatan mental adalah cabang kedokteran. Pada saat yang sama ia juga mampu memetakan dan mengklasifikasikan dari cabang-cabang lain seperti pandangan yang integral mengenai klasifikasi faktor-faktor yang menyebabkan gangguan psikologis, sejalan dengan klasifikasi itu mengenai penyebab gangguan psikologis meliputi: faktor psikologis dan perkembangan ( أسباب نفسية وتطورية), faktor sosial dan lingkungan ( أسباب اجتماعيةوبيئية), faktor utama yang berkaitan dengan kembalinya beberapa gangguan mental yang memberi dampak pada fisik tubuh, seperti phobia dan kecemasan. (الحزن و الوساوس) (Al-Balhi, 2005).

\section{Konsep Al-Balkhi dalam Menjaga Kesehatan Badan}

Dalam bab pertama mengenai menjaga kesehatan badan ( حفظ صحة الأبدان) a-Balkhi menggunakan metode pengetahuan yang singkat dan jelas sebagaimana ada pada prinsipprinsip umum dari ilmu kesehatan meliputi menjaga kesehatan lingkungan (حفظة البيئة), menjaga kesehatan tempat tinggal ( حفظ صحة المسكن), sanitasi air (الماء) dan udara (الهواء)). Oleh karena itu perlunya penentuan standar kualitas di semua bidang lingkungan dan memanfaatkan bidang ini serta mencarikan solusi untuk memastikan terpenuhinya kondisi kesehatan lingkungan tersebut (Al-Balhi, 2005).

Pentingnya menjaga tubuh pada waktu sehat dan sakit dan memberikan aturan kebersihan individu sebagai pelaku utama yang harus memenuhinya. Secara umum sebagaimana penyebab migrasi pada hewan-hewan tidak lain karena alasan utama menjaga kesehatan, disamping prinsip-prinsip lingkungan hidup, juga karena adanya kesalahan prinsipprinsip desain lingkungan, prinsip transisi dan prinsip lingkungan yang tumpang tindih, oleh karena itu hal ini sangat penting diperhatikan dalam meningkatkan kondisi kesehatan lingkungan tempat tinggal.

\section{Konsep Al-Balkhi dalam Menjaga Kesehatan Jiwa}

Dalam bab kedua mengenai menjaga kesehatan jiwa ( حفظ صحة الأنفس) al- al-Balkhi mengatakan bahwa orang terpapar penyakit jiwa sama seperti halnya terpapar pada tubuhnya, bahwa gejala psikologis lebih melekat pada manusia, dan karena itu kita wajib menjaga 
kesehatan jiwa tersebut (وبناء على ذلك اوجب رعاية مصالح النفس), dan juga menjaga diri gejolak meledakledak (ووقايتها من الاضطراب). ini membuktikan hubungan timbal balik antara kesehatan jiwa dan kesehatan tubuh yang memiliki pengaruh satu sama lain (Al-Balhi, 2005).

Al-Balkhi mengadopsi ukuran kesehatan jiwa pada apa yang disebutnya strategi (الحيل), dan membaginya menjadi dua bagian: strategi dari luar diri ( حيل من خارج النفس), tergantung pada bantuan dokter ( على مساعدة الطبيب). Adapun trik yang datang dari dalam jiwa, apa yang kita ketahui sekarang dengan cara menjaga dan melindungi diri sendiri (Al-Balhi, 2005).

\section{Model Perawatan/Psikoterapi}

Model perawatan/psikoterapi yang dilakukan oleh al-Balkhi seperti penanganan penyakit fobia, al-Balkhi melakukan tindakan pengobatan berdasarkan pada perilaku dan manajemen kognitif (behavior and thought management), tidak seperti pendahulunya dan orangorang sezamannya yang menganggap fobia sebagai gejala melankolis dan karenanya harus diobati dengan obat-obatan, Teknik terapi yang dijelaskan oleh al-Balkhi sangat mirip dengan terapi perilaku kontemporer. Dalam beberapa bagian dari manuskripnya, al Balkhi mendorong orang yang mengalami fobia untuk secara bertahap melatih indranya dan "nafs" (psyche) dengan tambahan paparan objek yang ditakuti. Dia merekomendasikan agar paparan tambahan ini dilakukan dengan secara bertahap melihat atau mendengarkan objek yang ditakuti. Al-Balkhi menyebut pendekatan perawatan ini, "reyadat al-nafs" yang berarti pelatihan jiwa (Awaad \& Ali, 2016).

\section{Konsep Keseimbangan Badan dan Jiwa}

Hasil karya al-Balkhi dapat dikatakan pandangan mendalam sebagai cermin yang jelas dari ilmu kesehatan di awal era kepenulisan medis awal Islam. Ilmu kedokteran telah mencapai lompatan kualitatif di tangan Balkhi dibandingkan dengan sebelumnya yaitu zaman Galen yang lebih mengutamakan kesehatan fisik. Apa yang layak disebutkan di sini adalah tidak menyebutkan kutipan Balkhi dari Hippocrates dan Galen, meskipun Balkhi mengambil dari pendahulunya seperti Tabari dan Razi, Meliputi topik merawat kesehatan dalam tulisan mereka, sebagaimana yang dilakukan Balkhi. Pertama buku Al-Balkhi ditandai dengan 
klasifikasi dan sistimatika yang baik, kedua koleksi materi yang ilmiah, dan Ketiga kualitas penyajian serta kemudahan informasi sejalan dengan tujuan penyebaran budaya medis. Di dalam bukunya Ia juga memakai pendekatan dan penjelasan, pendekatan sebab-akibat dan pengalaman praktis, serta dalam buku itu al-Balkhi mengadopsi metode berdasarkan inspirasi kebijaksa (Inspiration wisdom) (Badri, 2013b).

Al-Balkhi merupakan intelektual muslim pertama yang memperkenalkan psikologi dalam Islam mengenai Ilmu saraf (neuroscience), dia juga terkenal sebagai tokoh yang pertamakali menemukan psikologi kognitif dan medis (cognitive psychology and medical), juga yang pertamakali membedakan antara penyakit saraf (neurosis) dan penyakit jiwa (psychosis), serta orang yang pertama kali mengklasifikasikan gangguan saraf (neurotic disorders) dan perintis terapi kognitif (cognitive therapy) dan menunjukkan secara rinci bagaimana terapi kognitif dan spiritual secara rasional dapat digunakan untuk merawat dari masing-masing kelompok gangguannya.

Al-Balkhi mengklasifikasikan neurosis menjadi empat gangguan emosional: phobia dan kecemasan (fear and anxiety), kemarahan dan agresi (anger and aggression), kesedihan dan depresi (sadness and depression), dan obsesi (obsessions) (Haque, 2004). Dia juga mengkompensasi fisik dengan gangguan psikologis dan menunjukkan interaksi mereka dalam menyebabkan gangguan psikosomatik. Dia menyarankan bahwa sama seperti orang yang sehat menyimpan beberapa obat-obatan dan obat-obatan Pertolongan Pertama di dekatnya untuk keadaan darurat fisik yang tak terduga, dia juga harus menjaga pikiran dan perasaan sehat dalam pikirannya untuk ledakan emosi yang tak terduga. Demikian Al-Balkhi mengatakan bahwa keseimbangan antara pikiran dan tubuh yang membawa kesehatan dan ketidakseimbangan akan menyebabkan penyakit.

Al-Balkhi mengatakan bahwa untuk perawatan tubuh mengikuti pendekatan yang berlawanan dan timbal balik berkenaan dengan ketidakseimbangannya. Pendekatan ini disebut reciprocal inhibition (al-ilaj bi al-did) yang diperkenalkan oleh Joseph Wolpe pada tahun 1969 (Haque \& Kamil, 2012). Al-Balkhi mengklasifikasikan tiga jenis depresi (الحزن), meliputi depresi normal atau kesedihan, depresi endogen yang berasal dari dalam tubuh dan depresi reaktif yang berasal dari luar tubuh. (Haque, 2004) Individu yang sehat harus selalu menjaga kesehatan 
pikiran dan perasaan. Maka menurutnya, keseimbangan antara pikiran dan tubuh sangat diperlukan untuk memperoleh kesehatan yang prima, sebaliknya ketimpangan antara keduanya justru akan menimbulkan penyakit.

Konsep kesehatan dan mental individu menurutnya terkait erat dengan kesehatan spiritual. Dia adalah orang yang pertamakali berhasil mengkaji bermacam-macam penyakit yang secara langsung mempunyai keterkaitan antara fisik dan jiwa, seperti yang diulasnya dalam kitabnya Masalih al-Abdan wa al-Anfus (Kesehatan Badan dan jiwa). Al-Balkhi sering mengkritik dokter-dokter di zamannya karena selalu berfokus pada penyakit fisik dan mengabaikan penyakit mental dan kejiwaan para pasiennya. Dia berargumen bahwa dikarenakan konstruksi manusia terdiri dari jasmani dan rohani, maka keberadaannya tidak dapat dikatakan sehat tanpa adanya keterjalinan antara jiwa dan badan. Lebih lanjut dia mengatakan: "Jika badan sakit, jiwa pun akan banyak kehilangan kemampuan kognitifnya dan tidak dapat merasakan kenikmatan hidup". Sebaliknya "Jika jiwa sakit, badan pun kehilangan keceriaan hidup dan bahkan badannya pun dapat jatuh sakit". Pemikirannya ini sebagaimana disebutkan dalam al-Qur'an dan Sunnah. Di antaranya adalah QS. 2:10, "Dalam hati mereka ada penyakit". Dan Sabda Nabi: "Ketauhilah! Sesungguhnya dalam badan manusia itu ada segumpal daging, apabila ia baik maka seluruh badannya akan baik. Tetapi jika ia rusak, maka rusaklah seluruh badannya. Ketauhilah bahwa ia (segumpal daging) itu adalah kalbu". (HR. al-Bukhari).

\section{Kesimpulan}

Integrasi yang luar biasa antara unsur-unsur material dan spiritual sebagaimana yang dilakukan oleh Abu Zaid Al-Balkhi telah menjadi ciri peradaban Islam menarik semua ilmu yang berkembang dalam peradaban itu, termasuk kedokteran. Al-Balkhi mengetahui bahwa kesehatan umum manusia didasarkan pada keseimbangan antara kesehatan tubuh dan kesehatan jiwa, oleh karena itu dalam perawatannya perlu mengetahui faktor-faktor internal dan eksternal yang mengarah pada penyimpangan. Demikian konstruksi manusia terdiri dari jasmani dan rohani maka fokus perawatan tidak dapat dari sisi fisik saja namun harus dilihat sisi mental pasiennya. Al-Balkhi mengatakan eksistensi manusia tidak dapat dikatakan sehat tanpa adanya keterjalinan antara jiwa dan badan. Demikian: "Jika badan sakit, maka jiwa pun 
akan banyak kehilangan kemampuan kognitifnya dan tidak dapat merasakan kenikmatan

hidup". Sebaliknya Jika jiwa sakit, maka badan pun kehilangan keceriaan hidup dan bahkan badannya pun dapat jatuh sakit".

Saran

Disarankan kepada peneliti selanjutnya untuk melakukan penelitian lanjutan berupa penelitian kualitatif yang mendalam terkait keseimbangan badan dan jiwa perspektif Abu Zaid Al-Balkhi. Penelitian dalam bentuk kuantitatif juga disarankan untuk melihat keterkaitan keseimbangan badan dan jiwa perspektif Abu Zaid Al-Balkhi dengan atribut psikologi lainnya.

\section{Referensi}

Al-Faruqi, I. R. (1992). Al Tawhid: its implications for thought and life. Dalam Issues in Islamic thought.

Al-Balhi, A. Z. A. B. S. (2005). Masalih al-Abdan wal-Anfus (M. Misri, ed.). Cairo.

Al-Ghazālī. (1982). Iḥyā' 'ulūm al-Dīn (Vol.3). Beirut: Dār al-Ma rifa.

Al-Hamawi, Y. (1993). mu'jam al-adba': irshad al-arib ilaa ma'rifat al-adib (Ihsan Aeabbas, ed.). Beirut: dar al-Gharib al-Islami.

Ashy, M. A. (1999). Health and illness from an Islamic perspective. Journal of Religion and Health. https://doi.org/10.1023/A:1022984718794

Awaad, R., \& Ali, S. (2016). A modern conceptualization of phobia in al-Balkhi's 9th century treatise: Sustenance of the Body and Soul. Journal of Anxiety Disorders. https://doi.org/10.1016/j.janxdis.2015.11.003

Badri, M. (2013a). Abu Zayd Al-Balkhi's Sustenance of the Soul: The Cognitive Behavior Therapy of A Ninth Century Physician. London.

Badri, M. (2013b). Abu Zayd al-Balkhi's Sustenance of the Soul: The Cognitive Behavior Therapy of A Ninth Century Physician. London: International Institute of Islamic Thought (IIIT).

Haque, A. (2004). Psychology from Islamic perspective: Contributions of early Muslim scholars and challenges to contemporary Muslim psychologists. Journal of Religion and Health. https://doi.org/10.1007/s10943-004-4302-z

Haque, A., \& Kamil, N. (2012). Islam, Muslim, and Mental Health. Dalam Counseling Muslims: Handbook of Mental Health Issues and Interventions. New York: Routledge.

Mujib, A. \& Mudzakir, J. (2002). Nuansa-Nuansa Psikologi Islam. Jakarta: PT. Persada Grafindo Persada.

Nasr, S. H., \& Leaman, O. (2013). History of Islamic philosophy. Routledge. 